final pronouncements on the writings of Africans. Such western critics as Gerald Moore and Ulli Beier are known as critics of African literature. These names will have to go along with the first generation of writers whom they helped to attain world-wide recognition. The first generation of writers will have to be reassessed by this new breed of critics and the contribution of these writers recorded and accorded its proper place in our literature.

The implication of all these facts is that the foreigner interested in African literature is no longer going to have it delivered to his doorstep. He'll have to come out to us and get it, just as I would come to the United States to get the books of Chester Himes or Frank Yerby because this is where these books are. Naturally this is good for our economy and also for our ego!

Perhaps the most important result of this new generation of writers is the growth and development within Africa of a reading public. This is good for us, and one hopes that it will continue to grow and develop.

I wish to conclude on a note of personal affirmation: right now there are historical circumstances which make me and a number of other writers in Nigeria feel that we can look at such phrases as "political propaganda" and "prostitution of literature" as deliberate concessions made to the West by escapist writers among us. The historical circumstances in countries are naturally different. So you will write differently. In the long run, your treatment of the lot of Man in your country and my treatment of his lot in Nigeria will all add up to the treatment of the lot of universal Man in our time. By looking closely enough and truthfully enough at ourselves, we also look at mankind.

\title{
A Still Unmanageable Language
}

Literature is primarily language. The writer's obligation is to rebel against the old tongue and re-name things. But language is like blood in culture, and in cultural evolution there are no leaps in the dark. We rebel against a tradition when we have previously assumed it as ours. Thus, rebellion in language is also a consequence of feeling it as one's own. For us, coming from a colonial system, the order of the relation between language and things begins transposed: Castilian in Spain designated existing things; in Spanish America it pre-existed the things. The conquerors imposed a 
political power, an ideology and a language as instruments of colonization, and our world of references was European. Since then, passing through three centuries of colonial life, relative political independence and the monotonous dead end canyon of underdevelopment, our culture carries a marginal or peripheral quality within itself as its own tonality. Etymology is not our science; it is always over there. The metropolis towards which we look is never our city. In Chile the classics are undoubtedly from somewhere else. We are barbarians mentally condemned to besiege Rome. We needn't break off from any determined literary tradition; rather, take them all by storm. We grew up in the nostalgia of a Spanish language that was not made to see our reality but to compare it and find it similar to some other. For many years our literature has dressed with words and the dictionary has been a theatrical wardrobe.

In Chile we were born bastards: neither European nor Indian, not in the dining room or in the kitchen. In the region of massacred Indians there are Germans who are no longer Germans; in Valparaiso are Englishmen who convinced us we were the English of South America; in Santiago there are Frenchmen who impose the latest fashion, always late, Italians who lost their language to gain a dialect, and everywhere Spaniards, sons or grandsons of the motherland that, as José Donoso once said, was a great whore, in the best sense of the expression. We became independent trying to think like Frenchmen because it was the beginning the nineteenth century and Napoleon had invaded Spain, and we have become industrialized trying to think like North Americans, for obvious reasons. Alberto Blest-Gana, our principal novelist of the last century, wanted to be the Balzac and the Stendhal of Chile at the same time, and today, it is easy to perceive American English in the writers' syntax. We have gone along accommodating dependence in a very complex way and even our civil wars and governmental overthrows are programmed from outside the country. For that reason, although we don't have any bananas, the junta-guerrillas are trying to convince us that we are a "banana republic."

In Chile the old words were again filled with meaning. Spanish (previously Castilian) didn't change so much with new words or grammatical figures as because of the imagery of the traditionless barbarian whose only possible rebellion is piracy. Poets like Vicente Huidobro, Gabriela Mistral, Pablo de Rokha, Pablo Neruda, with very diverse fortunes, are examples of this attitude. They are united not by geneaology but the disposition to devour everything. They are the maximum expression of a time when poetry is still a problem of content in the most sumptuous form. The poet is a prophet, a "small god" or an energumen. There are no major changes in language and its structure, it is more what they leave obsolete than what they invent; their movement is to hurry the barbarian adventure to its last consequences (Neruda), show marginal lucidity, peripheral sagacity. 
Perhaps Neruda is only that: the great charlatan of the periphery. In this century it is possible to understand that our corniness has style because our condition as barbarians has been sufficiently established in time and geography to constitute a specific form of being, culturally, and we cornies have become the majority and maybe the norm; we could therefore be in a situation to invert the conditions: make ourselves classic, give the Europeans the chance to be barbarians. Alonso Ovalle promised us that, perhaps influenced by Don Quixote and Sancho (the second part) in his Histórica Relación del Reyno de Chile (Historic Narrative of the Kingdom of Chile) in the seventeenth century. And it is certain that our writers mean more to the Spanish today than current Spanish literature can mean to us; but we have to go to Barcelona to realize it. For Rubén Darío the loved one was from Paris; for Neruda she can be Parisian, Muscovite or Swedish. The system of references continues to be outside, but now, once in a while, one of us barbarians besieging Rome is admitted inside the walls of the city.

The first writer to lower his voice and write speaking more or less as we do was Manuel Rojas. As often happens, he learned to tell stories listening to his mother tell them. Likewise he made his characters think with the hyperbatons and ellipses of the vagabond anarchists he knew. In midcentury Nicanor Parra also took to spoken language, to graffiti, to press headlines to replace the lyric voice of the poet in favor of the many voices of Santiago, among which his own was sometimes heard. It was no longer a matter of the phonetic versions the "criollistas" (creole school) had attempted before; it was a matter of obtaining ways of thinking and saying through personal grammar. Various writers (Carlos Droguett, Fernando Alegría, José Donoso, Jorge Edwards) used colloquialism to define the characters' consciousness, but Nicanor Parra went beyond that and defined the structure of the poem (or anti-poem) through the structure of speech: it could be an advertisement in the paper, a newscast, a funeral speech, a prayer, a geometrical theorem, an apology, an insult ... Nicanor Parra does not affirm the poetic phenomenon or found a new rhetoric. He wants revolution in ideas. He is an iconoclast who begins by laying our myths in the dust, reducing language to the minimum and laughing at himself like Buster Keaton in verse. In Chile, with Parra, poetry and narration seem to come together. From a linguistic point of view, in the novel and short story after Manuel Rojas there is a refinement in the utilization of diverse local syntactical structures, recognizing little by little Chilean society's sectorization. With respect to form, considered more globally, there is a growing rehabilitation of the anecdote. Only the act of relating and its rhythm will give narrative tone and unity: the central story is the way it is told. Poets like Enrique Lihn and Jorge Tellier are also narrators, in their poetry as well as their stories; novelists like Alfonso Calderón and Hernán Valdés are also poets, in their novels as well as their poems. 
At the end of the sixties and beginning of the seventies, Chile lives the culmination of public paranoia flowing into the current schizophrenia. Literary petite histoire slowly disappears from the press and criticism of books becomes exceptional; Chilean writers begin to be edited outside the country; literary magazines die. It is not a time of meditation or reading; one only attends to today, perhaps tomorrow, a today and tomorrow that are always political. All the writers went underground, got together drinking wine in the Casa del Escritor, having coffee in the Gabriela Mistral building or at Universitaria Publishing Company, around their work in the Writers' Workshop of the Catholic University, in Quimantú Publishing Company, in the Spanish Department of the University of Chile. Some very intellectual magazines (Arbol de Letras, Ahora, Quinta Rueda, Mensaje, Cuadernos de la Realidad Nacional) picked up part of the literary debate. And never before had so many essays on the cultural phenomenon been published or had there been so much new Chilean literature in the bookstores.

During these years Chilean literature stopped being just an individual task organized by professors or a promotion of groups by individual enterprise; social conditions and initiatives seemed to harmonize and writers in general discussed their work. As at no preceding time the past was reviewed and the future projected in such a way that many of us knew what to expect from other writers and what others expected of us; the reading public didn't expect anything. The more the writer worried about cultural definition, the more the reader seemed to want to forget it. This situation protected the literary movement from mundane vanities. (The politicians' indifference saved us also from the dogma of socialist realism.) Paradoxically we matured; the act of narrating was converted into the dialectic of a search and, as Enrique Lihn would define it, the style was not the man but "the sum of his uncertainties." Everything was past because the minute was chronicled and we recuperated the transfigured biography; the most miserable truth was the poetic truth, and it was the only one, finally, that we had.

Paradoxically we matured (Enrique Lihn, Jorge Tellier, Hernán Valdés, Antonio Skarmeta, Mauricio Wacquez, Poli Délano, Ariel Dorfman ...), but we did it like good barbarians, attempting to connect everything-family, love, social struggle, the cultural experience of traveling, the means of communication and the subculture, the writer and his problems-in a story or a poem, with all levels of consciousness superimposed through an epiphanic act of narration. Success didn't torment us; we dreamed with words and they woke us with shots. We believed we were at the edge of a secret, but we were dispersed into exile, taking with us "a still unmanageable language."

Translated by Connie Sue McDuffee 